\title{
The European Community Respiratory Health Survey: what are the main results so far?
}

\author{
C. Janson*, J. Anto", P. Burney , S. Chinn ${ }^{\Uparrow}$, R. de Marco ${ }^{+}$, J. Heinrich ${ }^{\S}$, D. Jarvis ${ }^{\Uparrow}$, N. Kuenzlif \\ B. Leynaert**, C. Luczynska", F. Neukirch**, C. Svanes ${ }^{\# \#}$, J. Sunyer", M. Wjst' ${ }^{\S}$, on behalf of \\ the European Community Respiratory Health Survey II
}

The European Community Respiratory Health Survey: what are the main results so far? C. Janson, J. Anto, P. Burney, S. Chinn, R.de Marco, J. Heinrich, D. Jarvis, N. Kuenzli, B. Leynaert, C. Luczynska, F. Neukirch, C. Svanes, J. Sunyer, M. Wjst, on behalf of the European Community Respiratory Health Survey II. (C) ERS Journals Ltd 2001 .

ABSTRACT: The European Community Respiratory Heath Survey (ECRHS) was the first study to assess the geographical variation in asthma and allergy in adults using the same instruments and definitions. The database of the ECRHS includes information from $\sim 140,000$ individuals from 22 countries. The aim of this review is to summarize the results of the ECRHS to date.

The ECRHS has shown that there are large geographical differences in the prevalence of asthma, atopy and bronchial responsiveness, with high prevalence rates in English speaking countries and low prevalence rates in the Mediterranean region and Eastern Europe. Analyses of risk factors have highlighted the importance of occupational exposure for asthma in adulthood. The association between sensitization to individual allergens and bronchial responsiveness was strongest for indoor allergens (mite and cat). Analysis of treatment practices has confirmed that the treatment of asthma varies widely between countries and that asthma is often undertreated.

In conclusion, the European Community Respiratory Health Survey has shown that the prevalence of asthma varies widely. The fact that the geographical pattern is consistent with the distribution of atopy and bronchial responsiveness supports the conclusion that the geographical variations in the prevalence of asthma are true and most likely due to environmental factors.

Eur Respir J 2001; 18: 598-611.
*Dept of Medical Science: Respiratory Medicine and Allergology, Uppsala University, Sweden. ${ }^{\#}$ Respiratory and Environmental Health Research Unit, IMIM, Barcelona, Spain. "Dept of Public Health Sciences, King's College, London, Guy's Campus, London, UK.

${ }^{+}$Division of Epidemiology and Medical Statistics, University of Verona, Verona, Italy. ${ }^{8}$ Gesellschaft für Strahlenund Umweltforschung (GSF) - National Research Centre for Environment and Health, Institute of Epidemiology, Neuherberg, Germany. ${ }^{\text {Institute for }}$ Social and Preventive Medicine, University Basel, Dept of Environment \& Health, Basel, Switzerland. **INSERM U408 - Epidémiologie, Paris, France. $\#$ \#ept of Thoracic Medicine, Haukeland Hospital, Bergen, Norway.

Correspondence: C. Janson, Dept of Respiratory Medicine, Akademiska sjukhuset, SE-751 85 Uppsala, Sweden. Fax: 46186112819

\author{
Keywords: Asthma \\ atopy \\ epidemiology \\ incidence \\ prevalence \\ risk factors
}

Received: January 162001

Accepted after revision May 22001
During the first half of the 1990s, information on the variation in asthma prevalence, known or suspected risk factors for atopy and asthma, and information on the management of asthma in young adults was collected in the European Community Respiratory Health Survey (ECRHS).

The reason for undertaking the ECRHS was a rapid increase in the prevalence of asthma that had been reported from many different countries [1-4]. This increase was over too short a time period to be explained by genetic factors and must therefore have been related to nongenetic or environmental changes. Further evidence of the importance of environmental factors in asthma was that studies comparing prevalence in urban and rural areas in developing countries had shown large differences in asthma prevalence [5-7]. Treatment patterns of asthma [8] and asthma mortality [9] had been found to vary considerably in Europe which raised the question of whether the variation in mortality was due to geographical differences in the prevalence of asthma or differences in asthma fatality. Research directed towards identifying the environmental factors that explain this geographical variation in asthma was required to identify potential strategies to counter the global increase in the prevalence of asthma.

The information available on the variation in the prevalence of asthma and allergy at the beginning of the 1990s had been collected through several studies using different protocols. The ECRHS was, therefore, the first study that assessed the prevalence of asthma and allergic disease in a large number of countries 
using an identical and standardized protocol. The three main objectives of the survey were: 1) to estimate the variation in the prevalence of asthma, asthma-like symptoms, atopic sensitization and bronchial lability in Europe; 2) to estimate the variation in exposure to known or suspected risk factors for asthma, to measure their association with asthma and to assess further the extent to which they explain variations in the prevalence across Europe; and 3) to estimate the variation in treatment practice for asthma in the European Community.

Prior to the study, a two-stage plan for analysis was agreed in order to reduce the reporting of chance associations arising from multiple hypothesis testing based on the large combined ECRHS data set. Firstly, data from one or several centres within one country were analysed to examine potential risk factors for disease within the country. After the result of this analysis had been published, the analysis was then repeated using the combined ECRHS data set.

A large number of researchers and field workers from 22 countries have been involved in the study. The database of the ECRHS includes information on $\sim 140,000$ participants, and over 100 papers on different epidemiological aspects of asthma have been published from the ECRHS. It is now 10 yrs since the study began and the follow-up study, the European Community Respiratory Health Survey II (ECRHS II), has just started. It is therefore now an appropriate time to evaluate the results of the ECRHS so far. The aim of this review is to summarize the results of the ECRHS concerning variation in prevalence, known or suspected risk factors and asthma treatment. This review should be useful to all researchers investigating the epidemiology of asthma, and also to those interested in using the ECRHS data set in the future.

\section{Methodology of the study}

The protocol of the ECRHS was published in 1993 [10] and in an abbreviated form in 1994 [11]. Participating centres selected an area defined by preexisting administrative boundaries with a population of at least 150,000. When possible, an up-to-date sampling frame was used to randomly select at least 1,500 males and 1,500 females, aged 20-44 yrs.

In stage I, subjects were sent the ECRHS screening questionnaire asking about symptoms suggestive of asthma, the use of medication for asthma, and the presence of hay fever and nasal allergies.

In stage II, a smaller random sample of subjects who had completed the screening questionnaire were invited to attend for a more detailed interviewer-led questionnaire, skin-prick test (SPT), blood tests for the measurement of total and specific immunoglobulinE (IgE), spirometry and methacholine challenge. An additional sample of subjects, who had not been included in the random sample, but who had symptoms indicating asthma, were also invited to the extended examination.

\section{Questionnaires}

The screening questionnaire and the interviewer-led questionnaire were each developed from the questionnaire of the International Union Against Tuberculosis and Lung Diseases (IUATLD) [12, 13]. The interviewer-led questionnaire contained, among other items, questions on respiratory symptoms, selfreported asthma and allergic disorders, smoking habits, indoor environmental exposure, occupation and asthma treatment.

\section{Lung function and allergy testing}

Forced expiratory volume in one second (FEV1) and forced vital capacity (FVC) were measured with a standardized method. In most centres the lung function measurements were made with a Biomedin Spirometer (Biomedin, Padova, Italy), but other spirometers were used in some of the centres [14].

The methacholine challenge was carried out using a Mefar MB3 dosimeter (Mefar, Brescia, Italy). The methacholine was made up from lyophilized methacholine chloride (Provocholine, Hoffman La Roche, Basel, Switzerland). In most of the analyses of the complete data set, the ECRHS slope was used when measuring bronchial responsiveness [15]. The ECRHS slope was calculated by transforming the log slope (the regression slope of percentage decline in FEV1 with $\log _{10}$ dose). The rationale for the specific transformation used when calculating the ECRHS slope $(100 /(\log$ slope +10$))$ was to achieve uniform variance and normality [16].

Skin-prick testing was carried out using Phazets (Pharmacia Diagnostics, Uppsala, Sweden). The allergens selected in all centres included: Dermatophagoides pteronyssinus, cat, birch, timothy grass, Parietaria judaica, olive, ragweed, Cladosporium herbarum and Alternaria alternata. Each area could add up to two additional allergens of local importance. Total and specific IgE were measured (except in Melbourne, Australia and in Aarhus, Denmark) in one single laboratory using the Pharmacia CAP System (Pharmacia Diagnostics, Uppsala, Sweden). In all centres specific IgE was measured against D. pteronyssinus, timothy grass, cat and $C$. herbarum. In most centres specific IgE was also measured against a local allergen. These local allergens were birch for northern Europe, Parietaria for southern Europe and ragweed for United States, Australia and New Zealand.

\section{Quality control}

The quality control programme has been described elsewhere $[10,11]$. Briefly, the programme included training seminars before the study, quality control visits to each centre once during the study, monthly checks on nebulizer output and high performance liquid chromatography in a central laboratory in order to check the concentration of methacholine solutions from different centres. An extensive programme was also undertaken to check the locally 
entered data sets before including the data in the central ECRHS database.

\section{Results}

Forty-eight centres from 22 countries participated in stage 1 (table 1). At a later stage the ECRHS was also conducted in centres in Canada and Poland, but these data are, at present, not incorporated in the main ECRHS database. The median response rate was $78 \%$ (range $54-100 \%$ ). The total number of subjects that responded to stage 1 was 137,619 .

Five centres did not participate in stage 2 and five additional centres had to be excluded because of unsolvable problems with checking or linking stage 1 and stage 2 data. The combined data set for stage 2 therefore included 38 centres from 18 countries (table 1). The participation rate varied from $12-$ $90 \%$ (median $65 \%$ ). The random sample of stage 2

Table 1. - Available data in the combined European Community Respiratory Health Survey (ECRHS) data set from the 48 centres that participated in the ECRHS

\begin{tabular}{|c|c|c|c|c|c|}
\hline \multirow[t]{2}{*}{ Country } & \multirow[t]{2}{*}{ Centre } & \multirow{2}{*}{$\frac{\text { Stage 1 }}{\begin{array}{c}\text { Screening } \\
\text { questionnaire }\end{array}}$} & \multicolumn{3}{|c|}{ Stage 2} \\
\hline & & & $\begin{array}{c}\text { Interviewer led } \\
\text { questionnaire }\end{array}$ & $\begin{array}{l}\text { Methacholine } \\
\text { challenge }\end{array}$ & $\begin{array}{c}\text { Specific } \\
\text { IgE }\end{array}$ \\
\hline Iceland & Reykjavik & $\mathrm{x}$ & $\mathrm{x}$ & $\mathrm{x}$ & $\mathrm{x}$ \\
\hline Norway & Bergen & $\mathrm{x}$ & $\mathrm{x}$ & $\mathrm{x}$ & $\mathrm{x}$ \\
\hline \multirow[t]{3}{*}{ Sweden } & Goteborg & $\mathrm{x}$ & $\mathrm{x}$ & $\mathrm{x}$ & $\mathrm{x}$ \\
\hline & Umea & $\mathrm{x}$ & $\mathrm{x}$ & $\mathrm{x}$ & $\mathrm{x}$ \\
\hline & Uppsala & $\mathrm{x}$ & $\mathrm{x}$ & $\mathrm{x}$ & $\mathrm{x}$ \\
\hline Denmark & Aarhus & $\mathrm{x}$ & $\mathrm{x}$ & $\mathrm{x}$ & $\mathrm{x}$ \\
\hline Estonia & Tartu & $\mathrm{x}$ & $\mathrm{x}$ & & $\mathrm{x}$ \\
\hline \multirow[t]{3}{*}{ The Netherlands } & Bergen op Zoom & $\mathrm{x}$ & $\mathrm{x}$ & $\mathrm{x}$ & $\mathrm{x}$ \\
\hline & Geleen & $\mathrm{x}$ & $\mathrm{x}$ & $\mathrm{x}$ & $\mathrm{x}$ \\
\hline & Groningen & $\mathrm{x}$ & $\mathrm{x}$ & $\mathrm{x}$ & $\mathrm{x}$ \\
\hline \multirow{2}{*}{ Belgium } & Antwerp City & $\mathrm{x}$ & $\mathrm{x}$ & $\mathrm{x}$ & $\mathrm{x}$ \\
\hline & South Antwerp & $\mathrm{x}$ & $\mathrm{x}$ & $\mathrm{x}$ & $\mathrm{x}$ \\
\hline \multirow[t]{2}{*}{ Germany } & Erfurt & $\mathrm{x}$ & $\mathrm{x}$ & $\mathrm{x}$ & $\mathrm{x}$ \\
\hline & Hamburg & $\mathrm{x}$ & $\mathrm{x}$ & $\mathrm{x}$ & $\mathrm{x}$ \\
\hline Austria & Vienna & $\mathrm{x}$ & & & \\
\hline Switzerland & Basel & $\mathrm{x}$ & $\mathrm{x}$ & $\mathrm{x}$ & $\mathrm{x}$ \\
\hline \multirow[t]{5}{*}{ France } & Bordeaux & $\mathrm{x}$ & $\mathrm{x}$ & $\mathrm{x}$ & $\mathrm{x}$ \\
\hline & Grenoble & $\mathrm{x}$ & $\mathrm{x}$ & $\mathrm{x}$ & $\mathrm{x}$ \\
\hline & Montpellier & $\mathrm{x}$ & $\mathrm{x}$ & $\mathrm{x}$ & $\mathrm{x}$ \\
\hline & Nancy & $\mathrm{x}$ & & & \\
\hline & Paris & $\mathrm{x}$ & $\mathrm{x}$ & $\mathrm{x}$ & $\mathrm{x}$ \\
\hline \multirow[t]{5}{*}{ UK } & Cardiff & $\mathrm{x}$ & $\mathrm{x}$ & & $\mathrm{x}$ \\
\hline & Cambridge & $\mathrm{x}$ & $\mathrm{x}$ & $\mathrm{x}$ & $\mathrm{x}$ \\
\hline & Dundee & $\mathrm{x}$ & & & \\
\hline & Ipswich & $\mathrm{x}$ & $\mathrm{x}$ & $\mathrm{x}$ & $\mathrm{x}$ \\
\hline & Norwich & $\mathrm{x}$ & $\mathrm{x}$ & $\mathrm{x}$ & $\mathrm{x}$ \\
\hline \multirow{2}{*}{ Ireland } & Dublin & $\mathrm{x}$ & $\mathrm{x}$ & $\mathrm{x}$ & $\mathrm{x}$ \\
\hline & Kilkenny-Wexford & $\mathrm{x}$ & & & \\
\hline Greece & Athens & $\mathrm{x}$ & & & $\mathrm{x}$ \\
\hline \multirow[t]{3}{*}{ Italy } & Pavia & $\mathrm{x}$ & $\mathrm{x}$ & $\mathrm{x}$ & $\mathrm{x}$ \\
\hline & Turin & $\mathrm{x}$ & $\mathrm{x}$ & $\mathrm{x}$ & $\mathrm{x}$ \\
\hline & Verona & $\mathrm{x}$ & $\mathrm{x}$ & $\mathrm{x}$ & $\mathrm{x}$ \\
\hline \multirow[t]{6}{*}{ Spain } & Albacete & $\mathrm{x}$ & $\mathrm{x}$ & $\mathrm{x}$ & $\mathrm{x}$ \\
\hline & Barcelona & $\mathrm{x}$ & $\mathrm{x}$ & $\mathrm{x}$ & $\mathrm{x}$ \\
\hline & Galdakao & $\mathrm{x}$ & $\mathrm{x}$ & $\mathrm{x}$ & $\mathrm{x}$ \\
\hline & Huevla & $\mathrm{x}$ & $\mathrm{x}$ & $\mathrm{x}$ & $\mathrm{x}$ \\
\hline & Oviedo & $\mathrm{x}$ & $\mathrm{x}$ & $\mathrm{x}$ & $\mathrm{x}$ \\
\hline & Seville & $\mathrm{x}$ & & & \\
\hline \multirow[t]{2}{*}{ Portugal } & Coimbra & $\mathrm{x}$ & & & \\
\hline & Oporto & $\mathrm{x}$ & & & \\
\hline Algeria & Algiers & $\mathrm{x}$ & & & \\
\hline India & Mumbai (Bombay) & $\mathrm{x}$ & $\mathrm{x}$ & $\mathrm{x}$ & \\
\hline \multirow[t]{4}{*}{ New Zealand } & Auckland & $\mathrm{x}$ & & & \\
\hline & Christchurch & $\mathrm{x}$ & $\mathrm{x}$ & $\mathrm{x}$ & $\mathrm{x}$ \\
\hline & Hawkes Bay & $\mathrm{x}$ & $\mathrm{x}$ & $\mathrm{x}$ & $\mathrm{x}$ \\
\hline & Wellington & $\mathrm{x}$ & $\mathrm{x}$ & $\mathrm{x}$ & $\mathrm{x}$ \\
\hline Australia & Melbourne & $\mathrm{x}$ & $\mathrm{x}$ & $\mathrm{x}$ & $\mathrm{x}$ \\
\hline USA & Portland & $\mathrm{x}$ & $\mathrm{X}$ & $\mathrm{x}$ & $\mathrm{x}$ \\
\hline
\end{tabular}

IgE: immumoglobulin-E; $\mathrm{x}$ : included in the stated country. 


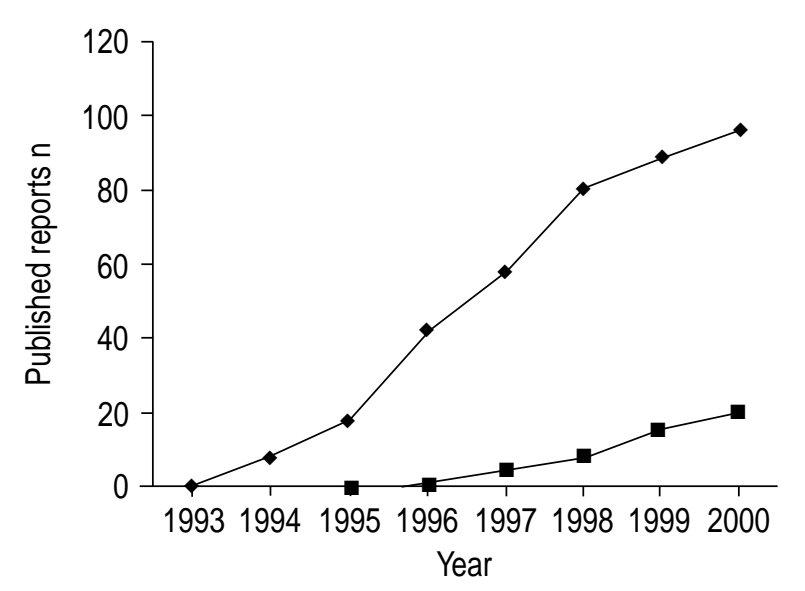

Fig. 1.-Published reports from the European Community Respiratory Health Survey. $\mathbf{\square}$ : central; $\diamond$ : local.

comprised 18,811 subjects. A symptomatic stage 2 sample was included in 25 centres and comprised 2,998 subjects.

Over 100 papers have been published from the ECRHS in English speaking journals, of which 20 have been based on analyses of the complete data set (central analyses) and the rest from analyses of data from one or several of the centres (local analyses) (fig. 1). In addition there have been a large number of papers published in languages other than English, but these papers are not part of this review. The published papers referred to in this review broadly fall into three categories: variation in prevalence and incidence, risk factors, and treatment practices.

\section{Variation in prevalence}

International and within country variation. The geographical variation in respiratory symptoms, asthma, allergic rhinitis, atopic sensitization and bronchial responsiveness has been described in four papers based on analysis of the combined ECRHS data set [17-20] (table 2). An eight-fold variation in the prevalence of wheeze and a four-fold variation in the prevalence of nasal allergy [17] were found in the analysis based on stage 1 data. A six-fold variation in the prevalence of current asthma was found when analysing stage 1 [17] or stage 2 data [20]. The prevalence of respiratory symptoms and asthma was found to be high in Australia, New Zealand, United States, Ireland and the UK and low in Iceland, parts of Spain, Germany, Italy, Algeria and India [17] (figs. 2 and 3).

Analysis of bronchial responsiveness showed an eight-fold variation in bronchial hyperresponsiveness (BHR) (provocative dose causing a $20 \%$ fall in FEV1 (PD20) $\leqslant 1 \mathrm{mg})$. The geographical distribution

Table 2. - Variation in the prevalence of respiratory symptoms, respiratory disease, sensitization, bronchial responsiveness, exposure and antiasthmatic treatment in the European Community Respiratory Health Survey (ECRHS)

\begin{tabular}{|c|c|c|c|c|}
\hline & Centres & Median & Range & Reference \\
\hline \multicolumn{5}{|l|}{ Symptoms } \\
\hline Wheeze & 48 & 20.7 & $4.1-32.0$ & [17] \\
\hline Waking with breathlessness & 47 & 7.3 & $1.5-11.4$ & {$[17]$} \\
\hline Waking with cough & 48 & 27.9 & $6.0-42.6$ & [17] \\
\hline \multicolumn{5}{|l|}{ Asthma and rhinitis } \\
\hline Current asthma (stage 1) & 48 & 4.5 & $2.0-11.9$ & [17] \\
\hline Current asthma (stage 2) & 34 & 5.2 & $1.2-13.0$ & [20] \\
\hline Nasal allergy and hay fever & 45 & 20.9 & $9.5-40.9$ & [17] \\
\hline \multicolumn{5}{|l|}{ Bronchial responsiveness } \\
\hline $\mathrm{PD}_{20} \leqslant 1 \mathrm{mg}$ & 35 & 13.0 & $3.4-27.8$ & [18] \\
\hline ECRHS slope (mean) & 35 & 7.6 & $6.7-8.4$ & [18] \\
\hline \multicolumn{5}{|l|}{ Allergic sensitization } \\
\hline Mite & 35 & 20.3 & $6.7-35.1$ & [19] \\
\hline Cat & 35 & 8.5 & $2.7-14.8$ & [19] \\
\hline Timothy & 35 & 18.0 & $8.1-34.6$ & [19] \\
\hline Cladosporium & 35 & 2.4 & $0.3-13.6$ & [19] \\
\hline Any allergen & 35 & 33.1 & $16.2-44.5$ & [19] \\
\hline $\operatorname{IgE}$ (geometric mean) $\mathrm{kU} \cdot \mathrm{L}^{-1}$ & 35 & 35.9 & $13.2-62.2$ & [19] \\
\hline \multicolumn{5}{|l|}{ Exposure } \\
\hline Male smokers* & 34 & 38 & $17-65$ & {$[14]$} \\
\hline Female smokers* & 34 & 33 & $14-52$ & [14] \\
\hline Gas stoves & 34 & 63.0 & $0-100$ & [21] \\
\hline Cat ownership & 35 & 20.1 & $3.7-68.6$ & {$[22]$} \\
\hline \multicolumn{5}{|l|}{ Heredity } \\
\hline Asthma prevalence in parents & 30 & 5.8 & $3.4-10.6$ & {$[23]$} \\
\hline \multicolumn{5}{|l|}{ Treatment } \\
\hline Asthma medication (stage 1) & 48 & 3.5 & $0.6-9.8$ & {$[17]$} \\
\hline Inhaled bronchodilators & 34 & 4.6 & $0.7-12.4$ & [20] \\
\hline Inhaled anti-inflammatory drugs & 34 & 2.8 & $0.3-8.2$ & {$[20]$} \\
\hline Oral antiasthmatics & 34 & 1.4 & $0.2-6.5$ & {$[20]$} \\
\hline
\end{tabular}

PD20: provocative concentration causing a $20 \%$ fall in forced expired volume in one second; IgE: immunoglobulin-E. *: subjects with asthma excluded. 


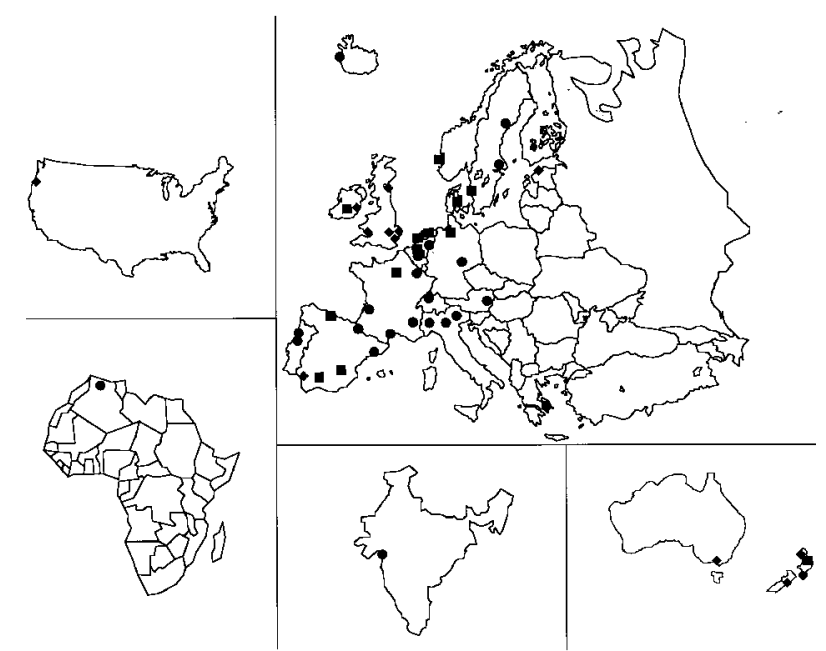

Fig. 2.-Geographical variation of wheeze (having had wheezing or whistling in the chest at any time within the last 12 months) [17]. : $<20 \%$; $: 20-25 \% ; \diamond:>25 \%$.

of bronchial responsiveness (ECRHS slope) and BHR fitted well with that for symptoms and asthma [18]. A wide geographical variation was also found when investigating the prevalence of atopic sensitization (specific IgE) [19]. A high prevalence was found in Australia, New Zealand, United Kingdom and United States, while the prevalence was low in Iceland, Greece, Norway, Italy and parts of Spain (fig. 4). The result of the analysis remained unchanged if local allergens were added. A five-fold variation was found in the geometric mean of total $\mathrm{IgE}$ but there was no correlation between total $\mathrm{IgE}$ and atopic sensitization [19].

The prevalence data from the International Study of Asthma and Allergy in Childhood (ISAAC) [24] was compared to the data from the ECRHS [25]. The prevalence estimates in the ECRHS were consistently lower than the prevalence rates in the 13-14 yrs age group in the ISAAC study. There was, however, generally a good correlation between the

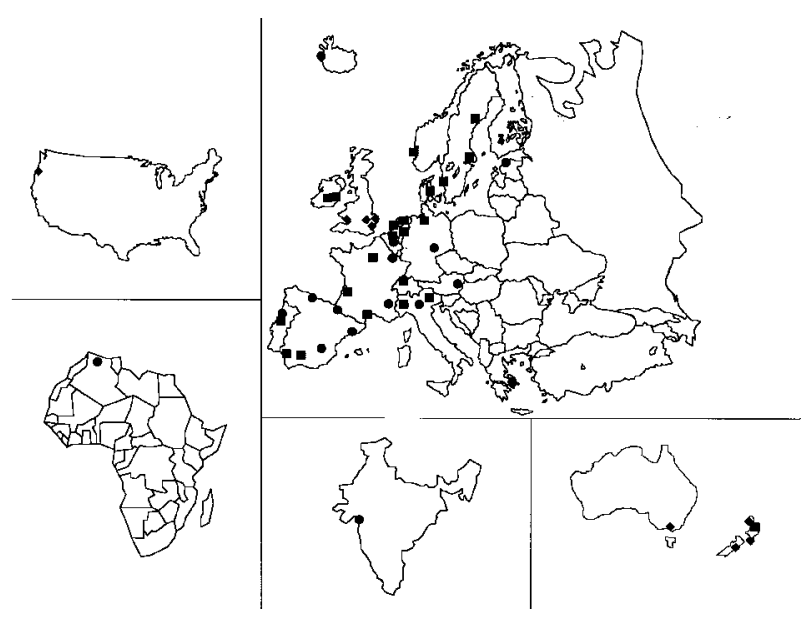

Fig. 3.-Geographical variation of asthma (having an attack of asthma in the last 12 months and/or currently taking medicine for asthma) [17]. ०: $<4 \%$; $: 4-7 \% ; \diamond:>7 \%$.

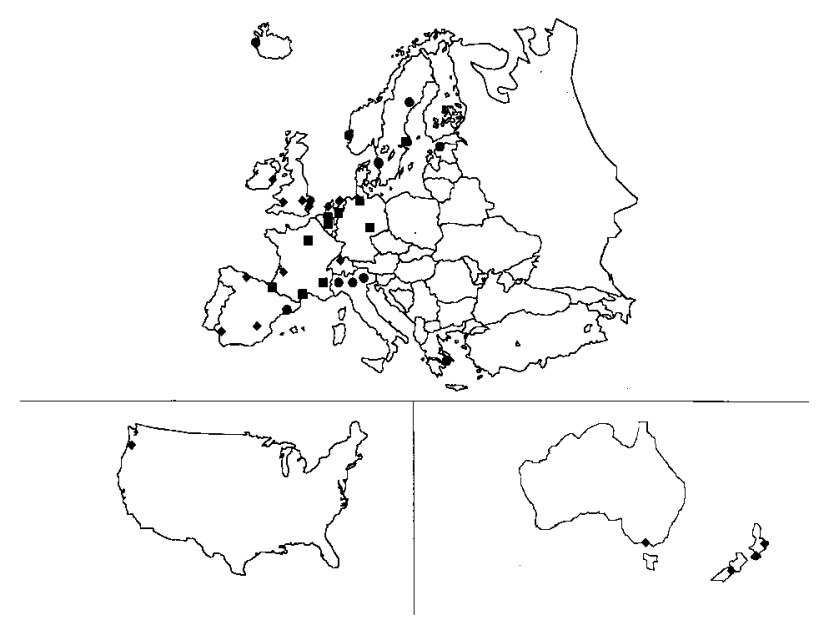

Fig. 4.-Geographical variation of atopy (positive specific immunoglobulin-E (IgE) against Dermatophagoides pteronyssinus, timothy grass, cat and/or Cladosporium herbarum $\left.\left(>0.35 \mathrm{kU} \cdot \mathrm{L}^{-1}\right)\right)$ [19-30]. : $<30 \%$; : $30-35 \%$; : $>35 \%$.

prevalence of wheeze, asthma and eczema in the ECRHS and the corresponding prevalence in the ISAAC study.

In order to evaluate if the variation of prevalence of respiratory symptoms between countries in the ECRHS was related to cultural or linguistic differences, SUNYER et al. [26] analysed the validity of reported respiratory symptoms in the interviewer-led questionnaire using factor analysis. Differences in the validity of questions using the term "asthma" was found between some countries. Otherwise the result of the analysis showed a good internal consistency suggesting that the experience of reporting symptoms is not affected by cross-cultural differences.

The wide variation in response was a concern to the project management team, particularly for the estimation and comparison of prevalence of symptoms, atopy, bronchial responsiveness and diagnosed asthma. This was addressed in two ways. In stage I, data on age and sex of nonrespondents were available from the sampling frame for almost all centres, and information was collected on the number of mailings to each responder before the questionnaire was returned. From these data, models to predict symptoms of nonresponders were developed, and these were used to estimate the effect of nonresponse on reported symptom prevalence [17]. It was concluded that differences in response rate between centres were a relatively minor source of variation compared to variation in the study as a whole.

Data from stage I were available for nonresponders to stage II. This enabled prevalence of sensitization to common allergens and the geometric mean of total $\mathrm{IgE}$ to be estimated by centre, with adjustment for nonresponse, based on outcome predicted by symptoms, age and sex [19]. The same approach was used for bronchial responsiveness [18] and physician diagnosed asthma [20]. In all papers the adjustment had almost no effect on the ranking of centres, and very little on size of effect in relation to between centre variation. 
Urban-suburban differences. In Belgium the prevalence of respiratory symptoms, asthma, atopic sensitization and BHR were found to be higher in Antwerp City than in suburban parts of southern Antwerp [27, 28]. In Verona (Italy), the prevalence of asthma was also found to be higher in urban than suburban areas [26].

East/West. Studies have shown that children from the former socialist Eastern European countries have lower prevalences of asthma and atopy than children in Western Europe [30, 31]. At the time of the survey there were no corresponding data on adult asthma and atopy. NowaK et al. [32] found that the prevalence of respiratory symptoms, asthma, nasal allergy, atopy and BHR was lower in Erfurt in former East Germany than in Hamburg. Correspondingly, the prevalence of asthma, nasal allergy and atopy was lower in Tartu in Estonia than in Uppsala in Sweden [33, 34]. The prevalence of wheeze and nocturnal respiratory symptoms was, however, higher in Tartu than in Uppsala [34].

In both studies, the difference in the prevalence of atopy was found to be greater in later birth cohorts than in earlier, indicating that change in childhood exposure in the sixties and seventies in Western Europe may explain the observed difference [33-35]. In Germany, a second stage 1 questionnaire was sent out to a new random population sample 3-4 yrs after the previous one. The result of this study showed that the prevalence rates of wheezing, asthma attacks, asthma medication and allergic rhinitis were stable in Hamburg but increasing in Erfurt and approaching those of Hamburg [36]. In a subsequent follow-up of the German stage 2 sample, the prevalence of BHR was found to have increased in subjects living in Erfurt, while BHR remained unchanged in the group of subjects from Hamburg [37].

Country of birth. The effect of immigration has so far only been reported in one paper. In an analysis of data from the Swedish centres, no difference was found in the prevalence of atopic sensitization in subjects born in the Nordic countries compared to those who were not [38]. The prevalence of sensitization to mite, ragweed and Cladosporium was higher and the prevalence of sensitization to birch and cat lower in subjects not born in the Nordic countries.

Incidence of asthma. As the ECRHS is a crosssectional survey, it was only possible to analyse the incidence of asthma retrospectively. The incidence of asthma was calculated from the reported age of the first attack of asthma. SuNYER et al. [39] found that in Spain, the incidence of asthma was higher in recent birth cohorts than earlier ones. In a subsequent analysis of the combined data set, the incidence rate of childhood asthma (0-15 yrs) was found to vary from 1.3 in Germany to 6.7 in Australia [40] per 1,000 person-yrs. The corresponding variation in the incidence of adult onset asthma was 0.3 in Belgium and the Netherlands to 2.9 in Australia. Subjects born in or later than 1966 had a two-fold higher risk of having had asthma attacks than the cohort born
1946-1950. In most countries, the risk of asthma increased progressively by birth cohort.

\section{Risk factors}

A summary of reported association in the ECRHS between known or suspected risk factors and wheeze, asthma, sensitization and bronchial responsiveness is presented in table 3. These are all within centre associations; only a few analyses have attempted to address the explanation of between centre variation $[22,41]$.

Age. The prevalence of wheeze and reported asthma was negatively related to age in several analyses of local data [42-45]. The prevalence of atopic sensitization was also negatively associated with age. This was found in analyses of local data [38, 46], as well as in an analysis of the combined ECRHS data set [47]. The level of total $\operatorname{IgE}$ was also negatively related to age [47]. As the ECRHS is a cross-sectional study, it is not possible to say whether these age-related differences in symptoms and atopic sensitization and symptoms were related to ageing or to a cohort effect.

Sex. Females have a higher prevalence of current asthma than males in several of the local analyses [48-50]. Sunyer et al. [39] found that females had a lower risk of asthma with onset before 15 yrs of age but a higher risk of adult onset asthma than males. In an analysis of the combined data set, DE MARCO et al. [51] found that the incidence of asthma was lower in females than in males during childhood. After the age of $15 \mathrm{yrs}$, females had an increased risk of incident asthma which was at least partly explained by smaller airway calibre (lower FEV1) in females than in males. In several analyses of local data sets, females had a higher prevalence of BHR than in males [32, 52-54]. In one study, this sex difference was explained by difference in airway geometry between females and males [55], while in other studies the prevalence of BHR remained higher in females, even after adjustment of airway calibre [52, 53]. A higher risk of sensitization to at least some allergens was found in males than in females in several analyses of local data sets $[32,38,46,56]$. This was also confirmed in an analysis of the combined ECRHS data set where JARVIS et al. [47] found that males were more likely to be sensitized to house dust mite and grass than females, while no sex difference was found in sensitization to cat. Total $\operatorname{IgE}$ was higher in males than in females.

Rhinitis. A higher prevalence of asthma in subjects with reported nasal allergy was found in several analyses of local data [43, 44, 49]. The association between perennial rhinitis and asthma was analysed using the combined ECRHS database [57]. Subjects with perennial rhinitis were more likely to have current asthma and BHR than subjects without perennial rhinitis. The association between perennial rhinitis and asthma remained significant after adjustment for possible confounders such as atopy, and was found in both atopic and nonatopic subjects [57]. Rhinitis 
Table 3.-Variables explaining variation in the prevalence of wheeze, asthma, atopic sensitization and bronchial responsiveness

\begin{tabular}{|c|c|c|c|c|}
\hline & Wheeze & Asthma & $\begin{array}{l}\text { Bronchial } \\
\text { responsiveness }\end{array}$ & $\begin{array}{c}\text { Atopic } \\
\text { sensitization }\end{array}$ \\
\hline Age & $(-)$ & $(-)$ & & - \\
\hline Female sex & & $\begin{array}{c}\text { (in childhood) } \\
+ \\
\text { (in adulthood) }\end{array}$ & $(+)$ & - \\
\hline Rhinitis & & + & + & + \\
\hline Allergic sensitization & $(+)$ & $(+)$ & + & \\
\hline Current smoking & $(+)$ & & $(+)$ & $\begin{array}{c}+ \\
(\text { to mite }) \\
- \\
\text { (to grass and cat) }\end{array}$ \\
\hline $\begin{array}{l}\text { Indoor environment } \\
\text { Gas cooking }\end{array}$ & $\begin{array}{c}+ \\
\text { (in women*) }\end{array}$ & & & \\
\hline Cat ownership & & & & $\stackrel{+}{+} \stackrel{+}{\text { (to cat in subjects without symptoms) }}$ \\
\hline Damp dwellings & $(+)$ & $(+)$ & $(+)$ & \\
\hline $\begin{array}{l}\text { Occupational exposure } \\
\text { Genetic disnosition }\end{array}$ & + & + & + & \\
\hline $\begin{array}{l}\text { Genetic disposition } \\
\text { Parental asthma }\end{array}$ & & + & $(+)$ & \\
\hline $\begin{array}{l}\text { Parental atopy } \\
\text { Childhood risk factors }\end{array}$ & & & & $(+)$ \\
\hline $\begin{array}{l}\text { Number of siblings } \\
\text { Dog in childhood } \\
\text { Cat in childhood }\end{array}$ & $(-)$ & $(-)$ & $(-)$ & $\begin{array}{c}- \\
- \\
- \\
\text { (to cat in subiects with atonic heredity) }\end{array}$ \\
\hline $\begin{array}{l}\text { Severe respiratory infections } \\
\text { before the age of } 5 \mathrm{yrs}\end{array}$ & & $(+)$ & & (to cat in subject \\
\hline
\end{tabular}

*: Heterogeneity between the centres; +: positive association; -: negative association; parentheses indicate the association was shown in local analysis, as opposed to the whole data set.

was also found to be an independent risk factor for onset of asthma when a subgroup of the Swedish stage 1 participants answered a new screening questionnaire, 3 yrs after the first one [58].

Allergic sensitization. Several investigations have found an association between allergic sensitization and asthma or BHR using local data sets [28, 32, 39, 49, $50,52-54,59-62]$. Cat sensitization was found to be the allergen most strongly associated with asthma and BHR in Sweden and the Netherlands $[50,58,60]$ while in India, Belgium and the UK the association with asthma or BHR was strongest for mite $[28,54,59]$. The attributable risk of atopic sensitization for BHR was found to be $19 \%$ in Sweden and 21\% in Spain [50, 63], while the attributable risk of atopy for current asthma was $26 \%$ and $42 \%$ in Sweden and Spain, respectively [50, 64]. In Spain, sensitization to Alternaria, olive, timothy grass and cat were found to be independent predictors for lower FEV1 after adjusting for smoking and bronchial responsiveness [65]. Sensitization to Alternaria was found to be a risk factor for severe asthma in an analysis of data from two French centres [66].

The association between allergic sensitization and bronchial responsiveness was studied in one analysis of the combined ECRHS data set [67]. Sensitization to mite, cat and timothy grass explained $1.4-12.7 \%$ of the total variation in bronchial responsiveness in the different centres. The variation of bronchial responsiveness was better explained by taking account of all the individual allergens than by classifying the subjects as atopic or nonatopic. Mite sensitization was the most important allergen in 15 centres, cat in eight, cat and mite equally in one, timothy in eight and Cladosporium in two. Total IgE was associated with BHR, independently of specific $\operatorname{IgE}$, both when analysing local data [61, 68] and when analysing the combined data set [67].

Smoking. As expected, a higher prevalence of wheeze and cough was found in current smokers than in nonsmokers in several of the local investigations [28, $44,69,70]$. The association between current smoking and asthma has been less clear. In a case-control study based on the combined data set, the risk of asthma with an onset within the last 3 yrs before the survey was found to be $43 \%$ lower in current smokers than in never smokers [51]. BJÖRNSSON et al. [44] found that the prevalence of reported asthma was similar in current smokers and nonsmokers while ABRAMsON et al. [49] reported a higher risk of current asthma in smokers than in nonsmokers. In a 3-yr follow-up study, PlaschKe et al. [58] found that onset of asthma was more common in current smokers than nonsmokers, but this effect of smoking was mainly found in nonatopic subjects.

In some local investigations, current smoking has 
been found to be an independent determinant of BHR [32, 52]. SunYER et al. [71] found, however, that smoking was associated with bronchial responsiveness only in nonatopic subjects, while LEYNAERT [53] reported that heavy smoking females had an increased risk of moderate-to-mild BHR, but no such association was found in males.

The association between smoking and atopic sensitization has been studied in several local analyses $[38,46,56]$ and in one analysis of the combined data set [47]. In the analysis of the combined ECRHS data set JARVIS et al. [47] reported a higher risk of sensitization to mite in smokers than never-smokers. The risk of sensitization to grass and cat was, however, lower in current and exsmokers than in never-smokers. Smoking was found to be positively associated with total $\mathrm{IgE}$, both in local analyses $[38,46,56]$ and in an analysis of the combined ECRHS data [47].

Indoor environment. In 1996 JARVIS et al. [72] reported that, in the UK, females who used gas cookers had an increased risk of wheeze and other asthma symptoms, as well as lower lung function (FEV1 and FEV1/ FVC) than females not using gas cookers. No such association was found in males. This report was followed by an analysis of the data from France which found the same results as in the UK [73], while in an analysis of data from the Belgium centres, no association was found between gas cooking and respiratory symptoms [74]. In a subsequent analysis of the combined data set, JARVIS et al. [21] reported that there was an overall association between the use of gas cookers and respiratory symptoms in females, but that this association varied considerably between the centres. In general, there was a positive association between gas cooking and symptoms in most European centres, but a negative association in Australia, New Zealand and the United States. The reason for this across-country heterogeneity was not explained, but could possibly be related to differences in the nature of the gas in different countries.

In 1999, Roost et al. [22] reported that there was an increased risk of cat sensitization in cat owners who did not have symptoms when exposed to pets. The community prevalence of cat ownership was found to be positively associated with the prevalence of cat sensitization in noncat owners. The community prevalence of cat ownership was also positively correlated with the prevalence of respiratory symptoms in the presence of pets, asthma and asthma medication [22].

In Uppsala, Sweden indoor exposure in the home and at the workplace was assessed by an additional questionnaire. Current asthma was more prevalent in subjects living in damp dwellings and particularly so in those living in dwellings with dampness in the floor construction [75]. Respiratory symptoms were found to be related to living or working in a newly painted dwelling, while BHR was related to living in a dwelling with newly painted wood details or kitchen painting [76].

In a subset of households in Uppsala, measurements of house dust mite levels, air borne microorganisms and concentration of volatile organic compounds (VOC) was performed. BJöRNSSON et al. [77] reported higher levels of house dust mite and airborne bacteria in houses of subjects with asthmarelated symptoms. This association was, however, not related to mite allergy, as none of the subjects who lived in houses with measurable house dust mite levels were sensitized to house dust mite. In a separate analysis on the same data set, NORBÄCK et al. [78] found that nocturnal breathlessness was associated with higher levels of carbon dioxide, formaldehyde and total concentration of VOC. Bronchial responsiveness was related to higher levels of terpenes.

Occupational exposure. The risk of asthma and respiratory symptoms attributable to occupational exposure was studied in analyses of the Spanish ECRHS data set [79] and the data set from New Zealand [80]. In both these investigations, a higher risk for asthma was found in laboratory technicians, and plastic and rubber workers. In New Zealand, the risk of asthma was also higher in farmers and farm workers [80]. The proportion of asthma attributed to occupational exposure was estimated to be $5-7 \%$ in Spain and $2-3 \%$ in New Zealand. In a subsequent analysis of the combined ECRHS data set, KogEvinAS et al. [81] found a higher risk for asthma in farmers, painters, plastic workers, cleaners and agricultural workers. Working as a cleaner increased the risk of asthma by $>30 \%$. After creating a job exposure matrix, asthma was found to be associated with high dose exposure to biological and mineral dust, as well as exposure to gases and fumes. The proportion of asthma attributed to occupational exposure was estimated to be $5-10 \%$.

In an analysis of data from the Swedish centres, workplace environmental tobacco smoke (ETS) was associated with workplace symptomatic asthma [82]. Having to leave a job because of breathing problems was associated with having worked in a job with a high risk for exposure to dust as well as workplace ETS.

Socioeconomic status. The association between socioeconomic status and respiratory health has received little analysis. KogEvinas et al. [70] reported that in the Spanish centres, bronchitis was more common in unemployed than employed subjects, even after adjusting for smoking, lung function and indoor risk factors.

Diet and medication. The questionnaires of the ECRHS included only a limited number of questions related to diet. Questions on fish consumption, weight and height were added in the Norwegian screening questionnaire. Reported fish consumption was not related to respiratory symptoms [83]. The authors did, however, find an increased risk of wheeze with increasing body mass index.

An ecological analysis was performed to measure international associations between paracetamol sales and atopic disease prevalences in children and adults [41]. Published data from ISAAC and ECRHS were used. Paracetamol sales were high in English-speaking countries, and were positively associated with asthma 
symptoms, eczema and allergic rhinoconjunctivitis in children (ISAAC), and with wheeze, diagnosed asthma, rhinitis and bronchial responsiveness in adults (ECRHS).

Infection. The role of current or recent infections has been analysed on local data from three centres. In Uppsala, subjects with serological signs of a current or recent Chlamydia pneumoniae infection were more likely to have reported wheeze than subjects without infections [84]. A correlation was also found between titres of $C$. pneumoniae immunoglobulin-A (IgA) antibodies and bronchial responsiveness. Conversely, in Verona, no significant association was found between $C$. pneumoniae titres and respiratory symptoms [85]. A relationship was found between serological sign of a recent respiratory syncytial virus infection and BHR in Uppsala [86].

Tuberculin reactivity was assessed with the adrenaline-Pirquet method at the stage 2 examination in Bergen in Norway [87]. The aim of this investigation was to test whether bacille Calmette-Guérin (BCG) immunization and subclinical exposure to Mycobacterium tuberculosis may influence a subject's inclination for developing allergic sensitization. No association was found between tuberculin reactivity and total serum IgE and specific serum IgE levels.

Genetic disposition. An association between asthma and parental asthma has been reported in several analyses of local data sets [28, 39, 49, 59]. Parental atopy was related to atopic sensitization in several of the local investigations $[29,33,38]$. The association between genetic disposition and asthma has also been studied in one analysis from the combined ECRHS data set [23]. Asthma was found to be related to parental asthma, and more so if both parents have asthma. The odds ratios for asthma in subjects with maternal and paternal asthma were 3.2 and 2.9, respectively. If both parents had asthma, the odds ratio for asthma increased to 7.0. The association did, however, vary between centres and regions. For developing extrinsic asthma (asthma in combination with nasal allergy or eczema), extrinsic asthma in any parent was a greater risk factor than intrinsic asthma (asthma but no allergic disease) in any parent. This implies that a genetic component is likely in atopic asthma, but the analysis does not exclude that a genetic component may also exist in nonatopic asthma. Different segregation models were applied which indicated that at least one major gene for asthma exists, but also that asthma is not fully described by a single gene model.

Childhood risk factors. The number of siblings has been found to be negatively related to current asthma $[39,88]$ and bronchial responsiveness [54] in analyses of local data sets. The number of siblings was also negatively related to atopic sensitization $[32,88]$. This was confirmed in an analysis of the combined data set [89]. In this analysis no significant association between birth order and atopy was found when taking in account the number of siblings.

Two central analyses have studied the association between pets in childhood and atopic sensitization. SvANES et al. [89] reported that atopy was negatively associated with having a dog in childhood, but that there was no significant association with having a cat as a child and atopy. Roost et al. [22] reported that having a cat in childhood was negatively associated with cat sensitization in subjects with a family history of atopy, while this association was not found in subjects without such a family history [22].

In local analyses, respiratory infection before the age of 5 yrs was found to be related to current asthma [49], childhood onset of asthma [39], ever having had asthma [28] and past asthma [90]. An association between current asthma and having been hospitalized for a lung disease before the age of 2 yrs, was found in an analysis of an extended screening questionnaire in Bergen in Norway [91]. No association was found between having had a serious respiratory infection in childhood and atopy when analysing the combined ECRHS data set [89].

In an analysis of the Swedish data set, an increased risk of atopic sensitization was found in subjects who had attended a day care centre before the age of 5 yrs [38], but this association was not found to be significant when analysing the combined data set [89].

In one local investigation, data from the screening questionnaire was linked with data from the birth weight register in Norway [92]. A decreased risk of respiratory symptoms was found with increasing birth weight. Respiratory symptoms were also inversely related to maternal age.

\section{Treatment practices}

Marked variations in treatment practices of asthma were found in analysis of the combined stage 1 data set. The use of asthma medication in subjects with attacks of asthma varied from $30 \%$ in Tartu in Estonia, to $>80 \%$ in the Netherlands, Sweden, New Zealand and the UK [17]. A wide cross-country variation was also found in the use of asthma medication in subjects with current asthma in analysis of the combined stage 2 data set [20]. The use of inhaled anti-inflammatory medication varied from $17 \%$ in Italy to $49 \%$ in the UK. A significant ecological association was found between the use of anti-inflammatory medication and the prevalence of doctor consultations. Few of the subjects with asthma reported use of alternative remedies except in Germany (16\%) and in Belgium (15\%) [20].

Two analyses of local data underlined that subjects with asthma are often undertreated. In a study from two French centres, 136 patients with asthma were identified [93]. An asthma severity score based on number of asthma attacks, symptoms, FEV1 and treatment was developed and validated. In both centres, most asthmatics were undertreated according to the international guidelines [94]. Similar results were obtained when analysing data from the Italian centres [95].

Some analyses have looked at how the use of asthma medication is influenced by factors other than asthma it self. Kogevinas et al. [70] found no 
difference in asthma medication use or the frequency of seeing a doctor in symptomatic unemployed or employed subjects. Unemployed subjects were, however, less likely to have been seen by a specialist. In an analysis of the combined ECRHS data set, current smoking was found to be an independent negative predictor of using antiasthmatic medication [96]. In many of the countries, females were more likely to be using medication than males, while no association was found between treatment and age or socioeconomic status. In another analysis of the combined data set, self-reported compliance was found to be low in asthmatics [97]. The level of compliance increased with age but was not related to sex or asthma severity (number of asthmatic attacks). A negative association was found between the prevalence of compliance per country and the proportion of asthmatics who had ever visited an emergency room or been hospitalized for breathing problems.

\section{Conclusion}

The ECRHS has shown that that there are large geographical differences in the prevalence of respiratory symptoms, asthma, bronchial responsiveness and atopic sensitization with high prevalence rates in English speaking countries and low prevalence rates in the Mediterranean region and Eastern Europe [17-20]. The geographical variation in variables related to asthma and allergy in young adults in the ECRHS is also in accordance with what has been shown in children in the ISAAC study $[25,98]$. Local analysis of the ECRHS have shown that the prevalence of atopic sensitization is lower in the former socialist Eastern Europe than in Western Europe [29, 33], which is in accordance to what has previously been found in children $[30,31]$.

Prior to the ECRHS, the patterns of geographical variation in asthma prevalence were mostly derived from questionnaire based surveys. The interpretation of these variations was limited by the possible influence of differences in study design, type of questionnaires and cross-cultural differences in the terms used in these questionnaires. The results from the ECRHS have shown that these differences persist when using the same standardized study protocol. In addition, the fact that the geographical pattern is consistent with the distribution of BHR supports the conclusion that the geographical variations are true and are most likely due to environmental factors. Furthermore, the ECRHS is unique in showing that the wide geographical differences in atopy are not accounted for by methodological factors such as the skin testing technique, the type of assay for the specific $\mathrm{IgE}$, the type of measurement, the type of allergens or the allergenic extracts manufacturer. The ECRHS has also enabled researchers to compare prevalence data of the ECRHS with that of other regions such as in Turkey and Albania using the ECRHS protocol [99-101].

The ECRHS is an ideal approach to formally assess geographical heterogeneity through meta-analysis and to suggest hypotheses about its origin. The ECRHS has highlighted the importance of occupational exposure for adult onset asthma with estimations that the proportion of asthma attributed to occupational exposure is $5-10 \%$ [81]. The associations between sensitization to individual allergens and bronchial responsiveness have been shown to be strongest for indoor allergens (mite and cat), but allergic sensitization only explains $1-13 \%$ of the total variation in bronchial responsiveness [67]. The explanation of why the use of gas cookers increases the prevalence of respiratory symptoms in females in some areas, but not in others, is unknown [21]. The possible association of other indoor exposure variables such as dampness in the dwelling and ETS with asthma has so far only been analysed in a small number of local ECRHS investigations [75, 82].

Even though the ECRHS is not ideally designed to analyse the effect of childhood exposure, the study has made important contributions to the knowledge on how childhood exposure influences atopic sensitization. In accordance with several other studies [102, 103], the ECRHS has shown that the likelihood of being atopic as an adult is inversely related to the number of siblings [89]. The results of the ECRHS indicate that pet exposure in childhood, especially exposure to dogs, reduces the risk of being sensitized as an adult [89], while cat exposure as an adult may have the opposite effect [22]. The study also confirms that parental asthma is an important risk factor for having atopic asthma as an adult [23].

The third objective of the ECRHS was to study international variations in treatment practices. In accordance with audits of asthma care [104] and statistics from drug sales [8], the treatment of asthma varies widely between the ECRHS centres [17, 20]. The ECRHS has also shown that, at least at the time of the study, asthma was still often undertreated [20, 93, 95].

In conclusion, the European Community Respiratory Health Survey has shown that the prevalence of asthma varies widely. The fact that the geographical pattern is consistent with the distribution of atopy and bronchial hyperresponsiveness supports the conclusion that the geographical variations in the prevalence of asthma are true and most likely due to environmental factors. The follow-up study, the European Community Respiratory Health Survey II, which has just started, will create internationally comparable data on changes in respiratory symptoms, atopic sensitization, bronchial responsiveness and lung function, thereby providing further clues as to how the global increase in the prevalence of asthma can be countered.

\section{References}

1. Burr ML, Butland BK, King S, Vaughan-Williams E. Changes in asthma prevalence: two surveys 15 years apart. Arch Dis Child 1989; 64: 1452-1456.

2. Åberg N. Asthma and allergic rhinitis in Swedish conscripts. Clin Exp Allergy 1989; 19: 59-63.

3. Robertson CF, Heycock E, Bishop J, Nolan T, Olinsky A, Phelan PD. Prevalence of asthma in 
Melbourne schoolchildren: changes over 26 years. BMJ 1991; 302: 1116-1118.

4. Ciprandi G, Vizzaccaro A, Cirillo I, Crimi P, Canonica GW. Increase of asthma and allergic rhinitis prevalence in young Italian men. Int Arch Allergy Immunol 1996; 111: 278-283.

5. Waite DA, Eyles EF, Tonkin SL, O'Donnell TV. Asthma prevalence in Tokelauan children in two environments. Clin Allergy 1980; 10: 71-75.

6. Van Niekerk CH, Weinberg EG, Shore SC, Heese HV, Van Schalkwyk J. Prevalence of asthma: a comparative study of urban and rural Xhosa children. Clin Allergy 1979; 9: 319-324.

7. Keeley DJ, Neill P, Gallivan S. Comparison of the prevalence of reversible airways obstruction in rural and urban Zimbabwean children. Thorax 1991; 46: 549-553.

8. Ruggieri F, Hindle M. Diagnosis and treatment of asthma across Europe. Eur Respir J 1989; 6: Suppl. 6, 536s-539s

9. Holland W. Atlas of avoidable Deaths. Commission of EC Health Services Research Series No. 3. Oxford, Oxford University Press, 1988.

10. European Community Respiratory Health Survey. Protocol for the European Community Respiratory Health Survey. Dept of Public Health Medicine, UMDS, St. Thomas' Campus, London, 1993.

11. Burney PG, Luczynska C, Chinn S, Jarvis D. The European Community Respiratory Health Survey. Eur Respir J 1994; 7: 954-960.

12. Burney P, Chinn S. Developing a new questionnaire for measuring the prevalence and distribution of asthma. Chest 1987; 91: 79S-83S.

13. Burney PG, Laitinen LA, Perdrizet S, et al. Validity and repeatability of the IUATLD (1984) Bronchial Symptoms Questionnaire: an international comparison. Eur Respir J 1989; 2: 940-945.

14. Roca J, Burgos F, Sunyer J, et al. References values for forced spirometry. Group of the European Community Respiratory Health Survey. Eur Respir $J$ 1998; 11: 1354-1362.

15. Chinn S, Arossa WA, Jarvis DL, Luczynska CM, Burney PG. Variation in nebulizer aerosol output and weight output from the Mefar dosimeter: implications for multicentre studies. Eur Respir J 1997; 10: 452 456.

16. Chinn S. Choosing a transformation. $J$ Applied Statistics 1996; 23: 395-404.

17. European Community Respiratory Health Survey. Variations in the prevalence of respiratory symptoms, self-reported asthma attacks, and use of asthma medication in the European Community Respiratory Health Survey (ECRHS). Eur Respir J 1996; 9: 687695.

18. Chinn S, Burney P, Jarvis D, Luczynska C. Variation in bronchial responsiveness in the European Community Respiratory Health Survey (ECRHS). Eur Respir $J$ 1997; 10: 2495-2501.

19. Burney P, Malmberg E, Chinn S, Jarvis D, Luczynska C, Lai E. The distribution of total and specific serum IgE in the European Community Respiratory Health Survey. J Allergy Clin Immunol 1997; 99: 314-322.

20. Janson C, Chinn S, Jarvis D, Burney P. Physiciandiagnosed asthma and drug utilization in the European Community Respiratory Health Survey. Eur Respir J 1997; 10: 1795-1802.

21. Jarvis D, Chinn S, Sterne J, Luczynska C, Burney P.
The association of respiratory symptoms and lung function with the use of gas for cooking. European Community Respiratory Health Survey. Eur Respir $J$ 1998; 11: 651-658.

22. Roost HP, Kunzli N, Schindler C, et al. Role of current and childhood exposure to cat and atopic sensitization. European Community Respiratory Health Survey. J Allergy Clin Immunol 1999; 104: 941-947.

23. European Community Respiratory Health Survey. Genes for asthma? An analysis of the European Community Respiratory Health Survey. Am J Respir Crit Care Med 1997; 156: 1773-1780.

24. Asher MI, Keil U, Anderson HR, et al. International Study of Asthma and Allergies in Childhood (ISAAC): rationale and methods. Eur Respir J 1995; 8: 483-491.

25. Pearce N, Sunyer J, Cheng S, et al. Comparison of asthma prevalence in the ISAAC and the ECRHS. ISAAC Steering Committee and the European Community Respiratory Health Survey. International Study of Asthma and Allergies in Childhood. Eur Respir J 2000; 16: 420-426.

26. Sunyer J, Basagana X, Burney P, Anto JM. International assessment of the internal consistency of respiratory symptoms. European Community Respiratory Health Study (ECRHS). Am J Respir Crit Care Med 2000; 162: 930-935.

27. Wieringa MH, Weyler JJ, Nelen VJ, et al. Prevalence of respiratory symptoms: marked differences within a small geographical area. Int J Epidemiol 1998; 27: 630635.

28. Wieringa MH, Weyler JJ, Van Bastelaer FJ, Nelen VJ, Van Sprundel MP, Vermeire PA. Higher asthma occurrence in an urban than a suburban area: role of house dust mite skin allergy. Eur Respir J 1997; 10: 1460-1466.

29. Campello C, Ferrari M, Poli A, et al. Prevalence of asthma and asthma-like symptoms in an adult population sample from Verona. ECRHS Verona. European Community Respiratory Health Survey. Monaldi Arch Chest Dis 1998; 53: 505-509.

30. von Mutius E, Fritzsch C, Weiland SK, Roll G, Magnussen $\mathrm{H}$. Prevalence of asthma and allergic disorders among children in united Germany: a descriptive comparison. BMJ 1992; 305: 1395-1399.

31. Bråback L, Breborowicz A, Dreborg S, Knutsson A, Pieklik H, Björksten B. Atopic sensitization and respiratory symptoms among Polish and Swedish school children. Clin Exp Allergy 1994; 24: 826-835.

32. Nowak D, Heinrich J, Jorres R, et al. Prevalence of respiratory symptoms, bronchial hyperresponsiveness and atopy among adults: west and east Germany. Eur Respir J 1996; 9: 2541-2552.

33. Jögi R, Janson C, Björnsson E, Boman G, Björksten B. Atopy and allergic disorders among adults in Tartu, Estonia compared with Uppsala, Sweden. Clin Exp Allergy 1998; 28: 1072-1080.

34. Jögi R, Janson C, Björnsson E, Boman G, Björksten B. The prevalence of asthmatic respiratory symptoms among adults in Estonian and Swedish university cities. Allergy 1996; 51: 331-336.

35. Heinrich J, Nowak D, Wassmer G, et al. Agedependent differences in the prevalence of allergic rhinitis and atopic sensitization between an eastern and a western German city. Allergy 1998; 53: 89-93.

36. Heinrich J, Richter K, Magnussen H, Wichmann HE. 
Is the prevalence of atopic diseases in East and West Germany already converging? Eur J Epidemiol 1998; 14: 239-245.

37. Richter K, Heinrich J, Jorres RA, Magnussen H, Wichmann HE. Trends in bronchial hyperresponsiveness, respiratory symptoms and lung function among adults: West and East Germany. INGA Study Group. Indoor Factors and Genetics in Asthma. Respir Med 2000; 94: 668-677.

38. Plaschke P, Janson C, Norrman E, et al. Skin prick tests and specific IgE in adults from three different areas of Sweden. Allergy 1996; 51: 461-472.

39. Sunyer J, Anto JM, Kogevinas M, et al. Risk factors for asthma in young adults. Spanish Group of the European Community Respiratory Health Survey. Eur Respir J 1997; 10: 2490-2494.

40. Sunyer J, Anto JM, Tobias A, Burney P. Generational increase of self-reported first attack of asthma in fifteen industrialized countries. European Community Respiratory Health Study (ECRHS). Eur Respir J 1999; 14: 885-891.

41. Newson R, Shaheen S, Chinn S, Burney P. Paracetamol sales and atopic disease in children and adults: an ecological analysis. Eur Respir $J$ 2000; 16 : 817-823.

42. Jarvis D, Lai E, Luczynska C, Chinn S, Burney P. Prevalence of asthma and asthma-like symptoms in young adults living in three east Anglian towns. $\mathrm{Br}$ J Gen Pract 1994; 44: 493-497.

43. Neukirch F, Pin I, Knani J, et al. Prevalence of asthma and asthma-like symptoms in three French cities. Respir Med 1995; 89: 685-692.

44. Björnsson E, Plaschke P, Norrman E, et al. Symptoms related to asthma and chronic bronchitis in three areas of Sweden. Eur Respir J 1994; 7: 2146-2153.

45. Abramson M, Kutin J, Czarny D, Walters EH. The prevalence of asthma and respiratory symptoms among young adults: is it increasing in Australia? J Asthma 1996; 33: 189-196.

46. Kerkhof M, Droste JH, de Monchy JG, Schouten JP, Rijcken B. Distribution of total serum IgE and specific IgE to common aeroallergens by sex and age, and their relationship to each other in a random sample of the Dutch general population aged 20-70 years. Dutch ECRHS Group, European Community Respiratory Health Study. Allergy 1996; 51: 770-776.

47. Jarvis D, Chinn S, Luczynska C, Burney P. The association of smoking with sensitization to common environmental allergens: results from the European Community Respiratory Health Survey. J Allergy Clin Immunol 1999; 104: 934-940.

48. Papageorgiou N, Gaga M, Marossis C, et al. Prevalence of asthma and asthma-like symptoms in Athens, Greece. Respir Med 1997; 91: 83-88.

49. Abramson M, Kutin JJ, Raven J, Lanigan A, Czarny D, Walters EH. Risk factors for asthma among young adults in Melbourne, Australia. Respirology 1996; 1: 291-297.

50. Plaschke P, Janson C, Norrman E, Björnsson E, Ellbjär S, Järvholm B. Association between atopic sensitization and asthma and bronchial hyperresponsiveness in swedish adults: pets, and not mites, are the most important allergens. J Allergy Clin Immunol 1999; 104: 58-65.

51. de Marco R, Locatelli F, Sunyer J, Burney P. Differences in incidence of reported asthma related to age in men and women. A retrospective analysis of the data of the European Respiratory Health Survey. Am J Respir Crit Care Med 2000; 162: 68-74.

52. Norrman E, Plaschke P, Bjornsson E, et al. Prevalence of bronchial hyperresponsiveness in the southern, central and northern parts of Sweden. Respir Med 1998; 92: 480-487.

53. Leynaert B, Bousquet J, Henry C, Liard R, Neukirch $\mathrm{F}$. Is bronchial hyperresponsiveness more frequent in women than in men? A population-based study. Am J Respir Crit Care Med 1997; 156: 1413-1420.

54. Chinn S, Jarvis D, Luczynska C, Burney P. Individual allergens as risk factors for bronchial responsiveness in young adults. Thorax 1998; 53: 662-667.

55. Wassmer G, Jorres RA, Heinrich J, Wjst M, Reitmeir $\mathrm{P}$, Wichmann HE. The association between baseline lung function and bronchial responsiveness to methacholine. Eur J Med Res 1997; 2: 47-54.

56. Jarvis D, Luczynska C, Chinn S, Burney P. The association of age, gender and smoking with total $\mathrm{IgE}$ and specific IgE. Clin Exp Allergy 1995; 25: 10831091.

57. Leynaert B, Bousquet J, Neukirch C, Liard R, Neukirch F. Perennial rhinitis: An independent risk factor for asthma in nonatopic subjects: results from the European Community Respiratory Health Survey. J Allergy Clin Immunol 1999; 104: 301-304.

58. Plaschke PP, Janson C, Norrman E, Björnsson E, Ellbjär S, Järvholm B. Onset and remission of allergic rhinitis and asthma and the relationship with atopic sensitization and smoking. Am J Respir Crit Care Med 2000; 162: 920-924.

59. Chowgule RW, Shyte V, Parmar J, et al. Prevalence of respiratory symptoms, bronchial hyperreactivity, and asthma in a megacity. Results of the European Community Respiratory Health Survey in Mumbai (Bombay). Am J Respir Crit Care Med 1998; 158: 547554.

60. Boezen HM, Postma DS, Schouten JP, Kerstjens HA, Rijcken B. PEF variability, bronchial responsiveness and their relation to allergy markers in a random population (20-70 yr). Am J Respir Crit Care Med 1996; 154: 30-35.

61. European Community Respiratory Health Survey Italy. Determinants of bronchial responsiveness in the European Community Respiratory Health Survey in Italy: evidence of an independent role of atopy, total serum IgE levels, and asthma symptoms. Allergy 1998; 53: 673-681.

62. Dharmage SC, Abramson M, Raven J, Thien FC, Walters EH. Why do only some of the young adults with bronchial hyperreactivity wheeze? J Asthma 1998; 35: 391-399.

63. Soriano JB, Tobias A, Kogevinas M, et al. Atopy and nonspecific bronchial responsiveness. A populationbased assessment. Spanish Group of the European Community Respiratory Health Survey. Am J Respir Crit Care Med 1996; 154: 1636-1640.

64. Soriano JB, Anto JM, Sunyer J, et al. Risk of asthma in the general Spanish population attributable to specific immunoresponse. Spanish Group of the European Community Respiratory Health Survey. Int J Epidemiol 1999; 28: 728-734.

65. Sunyer J, Soriano J, Anto JM, et al. Sensitization to individual allergens as risk factors for lower FEV1 in young adults. European Community Respiratory Health Survey. Int J Epidemiol 2000; 29: 125-130.

66. Neukirch C, Henry C, Leynaert B, Liard R, Bousquet 
J, Neukirch F. Is sensitization to Alternaria alternata a risk factor for severe asthma? A population-based study. J Allergy Clin Immunol 1999; 103: 709-711.

67. Chinn S, Burney P, Sunyer J, Jarvis D, Luczynska C. Sensitization to individual allergens and bronchial responsiveness in the ECRHS. European Community Respiratory Health Survey. Eur Respir J 1999; 14: 876-884.

68. Sunyer J, Anto JM, Castellsague J, Soriano JB, Roca J. Total serum IgE is associated with asthma independently of specific IgE levels. The Spanish Group of the European Study of Asthma. Eur Respir J 1996; 9: 1880-1884.

69. Ludviksdottir D, Björnsson E, Janson C, Boman G. Habitual coughing and its associations with asthma, anxiety, and gastroesophageal reflux. Chest 1996; 109 : $1262-1268$.

70. Kogevinas M, Anto JM, Tobias A, et al. Respiratory symptoms, lung function and use of health services among unemployed young adults in Spain. Spanish Group of the European Community Respiratory Health Survey. Eur Respir J 1998; 11: 1363-1368.

71. Sunyer J, Anto JM, Kogevinas M, Soriano JB, Tobias A, Munoz A. Smoking and bronchial responsiveness in nonatopic and atopic young adults. Spanish Group of the European Study of Asthma. Thorax 1997; 52: 235-238.

72. Jarvis D, Chinn S, Luczynska C, Burney P. Association of respiratory symptoms and lung function in young adults with use of domestic gas appliances. Lancet 1996; 347: 426-431.

73. Leynaert B, Liard R, Bousquet J, Mesbah H, Neukirch F. Gas cooking and respiratory health in women. Lancet 1996; 347: 1052-1053.

74. Wieringa $\mathrm{M}$, Weyler $\mathrm{J}$, Vermeire P. Absence of association between respiratory symptoms in young adults and use of gas stoves in Belgium. Lancet 1996; 347: 1490-1491.

75. Norbäck D, Björnsson E, Janson C, Palmgren U, Boman G. Current asthma and biochemical signs of inflammation in relation to building dampness in dwellings. Int J Tubercul Lung Dis 1999; 3: 368-376.

76. Wieslander G, Norbäck D, Björnsson E, Janson C, Boman G. Asthma and the indoor environment: the significance of emission of formaldehyde and volatile organic compounds from newly painted indoor surfaces. Int Arch Occup Environ Health 1997; 69: 115-124.

77. Björnsson E, Norbäck D, Janson C, et al. Asthmatic symptoms and indoor levels of micro-organisms and house dust mites. Clin Exp Allergy 1995; 25: 423-431.

78. Norbäck D, Björnsson E, Janson C, Widström J, Boman G. Asthmatic symptoms and volatile organic compounds, formaldehyde, and carbon dioxide in dwellings. Occup Environ Med 1995; 52: 388-395.

79. Kogevinas M, Anto JM, Soriano JB, Tobias A, Burney P. The risk of asthma attributable to occupational exposures. A population-based study in Spain. Spanish Group of the European Asthma Study. Am J Respir Crit Care Med 1996; 154: 137-143.

80. Fishwick D, Pearce N, D'Souza W, et al. Occupational asthma in New Zealanders: a population based study. Occup Environ Med 1997; 54: 301-306.

81. Kogevinas M, Anto JM, Sunyer J, Tobias A, Kromhout H, Burney P. Occupational asthma in Europe and other industrialised areas: a populationbased study. European Community Respiratory
Health Survey Study Group. Lancet 1999; 353: $1750-1754$.

82. Blanc PD, Ellbjär S, Janson C, et al. Asthma-related work disability in Sweden. The impact of workplace exposures. Am J Respir Crit Care Med 1999; 160: 2028-2033.

83. Fluge O, Omenaas E, Eide GE, Gulsvik A. Fish consumption and respiratory symptoms among young adults in a Norwegian community. Eur Respir J 1998; 12: $336-340$

84. Björnsson E, Hjelm E, Janson C, Fridell E, Boman G. Serology of chlamydia in relation to asthma and bronchial hyperresponsiveness. Scand $J$ Infect Dis 1996; 28: 63-69.

85. Ferrari M, Poli A, Olivieri M, et al. Seroprevalence of Chlamydia pneumoniae antibodies in a young adult population sample living in Verona. European Community Respiratory Health Survey (ECRHS) Verona. Infection 2000; 28: 38-41.

86. Björnsson E, Hjelm E, Janson C, Fridell E, Boman G. Serology of respiratory viruses in relation to asthma and bronchial hyperresponsiveness. Upsal J Med Sci 1996; 101: 159-168.

87. Omenaas E, Jentoft HF, Vollmer WM, Buist AS, Gulsvik A. Absence of relationship between tuberculin reactivity and atopy in $\mathrm{BCG}$ vaccinated young adults. Thorax 2000; 55: 454-458.

88. Jarvis D, Chinn S, Luczynska C, Burney P. The association of family size with atopy and atopic disease. Clin Exp Allergy 1997; 27: 240-245.

89. Svanes C, Jarvis D, Chinn S, Burney P. Childhood environment and adult atopy: results from the European Community Respiratory Health Survey. J Allergy Clin Immunol 1999; 103: 415-420.

90. Ferrari M, Tardivo S, Zanolin ME, et al. Serious childhood respiratory infections and asthma in adult life. A population based study. ECRHS Italy. European Community Respiratory Health Survey. Ann Allergy Asthma Immunol 1999; 83: 391-396.

91. Svanes C, Omenaas E, Eide GE, Fluge O, Gulsvik A. Hospitalization for lung disease in early childhood and asthma symptoms in young adulthood. Respir Med 1998; 92: 1003-1009.

92. Svanes C, Omenaas E, Heuch JM, Irgens LM, Gulsvik A. Birth characteristics and asthma symptoms in young adults: results from a population-based cohort study in Norway. Eur Respir J 1998; 12: 1366-1370.

93. Bousquet J, Knani J, Henry C, et al. Undertreatment in a nonselected population of adult patients with asthma. J Allergy Clin Immunol 1996; 98: 514-521.

94. National Heart, Lung, and Blood Institute, National Institute of Health. International Consensus Report on the diagnosis and managment of asthma. NIH publication number 92-3091, 1992.

95. Cerveri I, Zoia MC, Bugiani M, et al. Inadequate antiasthma drug use in the north of Italy. Eur Respir $J$ 1997; 10: 2761-2765.

96. Janson C, Chinn S, Jarvis D, Burney P. Individual use of antiasthmatic drugs in the European Community Respiratory Health Survey. Eur Respir J 1998; 12: 557-563.

97. Cerveri I, Locatelli F, Zoia MC, Corsico A, Accordini $\mathrm{S}$, de Marco $\mathrm{R}$. International variations in asthma treatment compliance: the results of the European Community Respiratory Health Survey (ECRHS). Eur Respir J 1999; 14: 288-294.

98. The International Study of Asthma and Allergies in 
Childhood (ISAAC) Steering Committee. Worldwide variation in prevalence of symptoms of asthma, allergic rhinoconjunctivitis, and atopic eczema: ISAAC. Lancet 1998; 351: 1225-1232.

99. Saraclar Y, Cetinkaya F, Tuncer A, et al. The prevalence of self-reported asthma and respiratory symptoms in Ankara, Turkey. Respir Med 1997; 91: 461-463.

100. Priftanji AV, Qirko E, Layzell JC, Burr ML, Fifield R. Asthma and allergy in Albania. Allergy 1999; 54: 1042-1047.

101. Celik G, Mungan D, Bavbek S, et al. The prevalence of allergic diseases and atopy in Ankara, Turkey: a two-step population-based epidemiological study. J Asthma 1999; 36: 281-290.

102. von Mutius E, Martinez FD, Fritzsch C, Nicolai T, Reitmeir P, Thiemann HH. Skin test reactivity and number of siblings. BMJ 1994; 308: 692-695.

103. Strachan DP, Harkins LS, Johnston ID, Anderson HR. Childhood antecedents of allergic sensitization in young British adults. J Allergy Clin Immunol 1997; 99: 6-12.

104. Vermeire P. Differences in asthma management around the world. Eur Respir Rev 1994; 4: 279-281. 